\title{
Seventy five years of limnology at the Istituto Italiano di Idrobiologia in Pallanza
}

\author{
Marina MANCA, Roberto BERTONI \\ CNR Institute of Ecosystem Study (ISE), Largo Tonolli 50, 28922 Verbania Pallanza, Italy \\ *Corresponding author: m.manca@ise.cnr.it
}

\begin{abstract}
The limnological research conducted at the Istituto Italiano di Idrobiologia over the last 75 years has taken an ecological and interdisciplinary approach, addressing the interdependence of chemical, physical and biological aspects of freshwaters. In this paper we have tried to reconstruct the evolution of this historic institute's activities, analyzing how theoretical and applied limnology have coexisted as the interests of researchers and funding agencies have changed. Theoretical developments of great ecological interest and effective models for the management of inland waters have emerged from this coexistence. Our aim is to trace the co-development of theoretical and applied limnology through the institute's scientific output and to indicate the future direction of limnological research.
\end{abstract}

Key words: limnology, Istituto Italiano di Idrobiologia.

Received: December 2013. Accepted: January 2014.

\section{INTRODUCTION}

"In dealing with any aspect of limnology, as perhaps any other branch of science, it is impossible to avoid the thought that no work is perfect and that the greater proportion of published investigations are very imperfect indeed. Every one of us is at fault in some way or another, every one of us must attempt to achieve progressively higher standards in accuracy, scope and imagination".

G.E. Hutchinson (1966; The prospect before us)

When the Istituto Italiano di Idrobiologia was founded 75 years ago, its mission, as indicated in its name, was the study of freshwater hydrobiology. However, from the outset the scientists working there took a much broader approach to research as they were well aware that inland waters could only be studied from an ecological viewpoint, that took into account abiotic components from chemistry to physics and through to climatology (Baldi, 1942). In addition, our colleagues of that time were aware of the obvious practical reasons for the study of inland waters, an essential resource for life on our planet. Theoretical and applied limnology have therefore always coexisted within the institute, with one prevailing over the other on the basis of changing cultural and economic demands.

Since its start 75 years ago, the Institute has published more than 3600 papers, 741 of them in the Memorie dell'Istituto italiano di Idrobiologia (issued from 1939 to 1998) and 455 in its continuation, the Journal of Limnology (from 1999). The early volumes of the Memorie were largely in Italian and mainly, but not exclusively, brought together the results of the institute's researchers. A number of leading figures in limnology published important pa- pers in the journal (Hutchinson, 1959; Margalef, 1965, 1990; Vollenweider, 1990). Over the years the Memorie became increasingly open to the limnological community as a whole and addressed an international audience, evolving into the Journal of Limnology, an open access peer reviewed journal, now ranked by IF in $10^{\text {th }}$ place among the 20 limnological journals indexed by ISI.

It is difficult to disentangle the strands of theoretical and applied limnology within that mass of publications, because separation is neither always obvious nor always possible. We made an attempt in this direction by analyzing a few specific issues in order to provide readers with a tool for assessing the manner and the extent to which the Institute's research has contributed to the general development of ecology.

\section{Lakes as suitable models for studying microevolutionary processes and genes expression}

Within the context of population studies, perspectives and potentialities of genetic analyses for limnological studies have been highlighted since the Institute's foundation. According to Baldi and Pirocchi (1939), the apparent contrast between cosmopolitanism and physiognomic insularity of lake biota was addressed as resulting from different space and time combinations of basically common components (lake dynamic individuality), in a mosaic-like infinite number of combinations. Fractionation of species into local forms was attributed to a genetic peculiarity deriving from the geographic fragmentation and insularity of lakes, in a manner similar to but with better support than suggested by Dobzhansky (1937) regarding varieties of mollusk shells independent 
from geographical sequences or peculiarities of the environment. Such traits were generally regarded as indicative of lakes being particularly well suited to studies on population genetics and microevolution.

Biological insularity and suitability of lakes for testing mechanisms of microevolution was further stressed by Baldi and Pirocchi (1939), who pointed out how local differences offered a unique opportunity, even better than that of terrestrial and marine habitats, for quantifying phenotype differences among endemotypes and of their distribution in relation with geographical distance and ecological distinctness of sites from which they were found. The approach proposed by Baldi was, as written by himself, addressed towards a plastic interpretation of landscape (similar to Wright's evolutionary landscapes or fitness landscapes [1932], metaphors used to attempt to explain how a population may move across an adaptive valley to a higher adaptive peak). This approach was applied for the first time to study the fragmentation of a population into genetically distinct subpopulations in Lake Maggiore, specifically the copepod species Mixodiaptomus laciniatus Lill. (Baldi et al., 1945a) thanks to the contributions of Buzzati-Traverso and Cavalli-Sforza who joined Baldi and his assistant Livia Pirocchi in their study of lake plankton populations (Buzzati-Traverso and $\mathrm{Ca}$ valli, 1945). This is the first study documenting scientific cooperation between Italian population geneticists and limnologists and it was no coincidence that it looked at zooplankton, on which Pirocchi had focused interest in quantifying population fractionation by means of morphometry, quantitatively analysed thanks to cooperation with Cavalli and Tonolli (Baldi et al., 1949), and which were assessed with statistical techniques by Cavalli (1949). Such collaboration was also facilitated by the fact that during the Second World War the pair were accommodated and hidden at the headquarters of the Institute, Villa De Marchi. They were assisted in investigating their specific fields and experimental organisms of interest and supported in publishing the results of their experimental and review studies regarding general issues in biology (Buzzati-Traverso, 1945). Although covering a relatively short time window, these studies pioneered modern interest in lakes as laboratories for studying microevolutionary patterns. Such interest was clearly expressed, once more, by Baldi (1950).

\section{Studies on taxa diversity, abundance, spatial and temporal distribution}

Studies on taxa diversity, abundance, spatial and temporal distribution, were at first largely devoted to plankton organisms, particularly those of Alpine aquatic environments. Not only lakes, but also ponds were included, as sources of endemic and rare organisms, classified through diagnostic traits in morphology and size. The early re- search shows a gradual transition from a descriptive, naturalistic approach to a truly ecosystemic approach to the study of lakes, assessing the various biotic and abiotic components of the ecosystem and relating them both to each other and to the characteristics of the surrounding territory (Baldi, 1941, 1942; Baldi et al., 1945b). In the fifties, progress in limnological knowledge was made possible thanks to increasingly sophisticated sampling techniques and the use of appropriate new sampling tools (Tonolli, 1951, 1954), along with awareness of, for example, vertical and horizontal heterogeneity of organisms, similarly to that already observed in marine plankton. Extensive studies were carried out to compare abundance and distribution of plankton populations and to investigate among-site phenological differences, and their seasonal changes. Results of these studies became classics, not least with Bossone and Tonolli (1954), among the first to prove with field data the validity of ecological theories, namely (invertebrate) predation allowing coexistence between closely-related, competing species. The study in fact dealt with the zooplankton of an Alpine lake, in which fish predation could be ruled out. This, as well as studies such as the one by Ravera (1955) on the seasonal succession of plankton copepods in Lake Maggiore, including the contribution of different developmental stages to species population density, and their resulting from duration length and stage-specific mortality, are classics in limnological literature. Hutchinson used figures included therein to illustrate patterns and mechanisms driving plankton seasonal succession in his Treatise on Limnology (1957). Incorporating results of limnological studies carried out at the Institute was the sign that Pallanza was becoming a focal point in limnological network, the outcome of intense scientific relationships with scientists who were developing and summarizing basic concepts in limnology. The cultivation of the scientific exchange of ideas at an international level, which is testified by extensive documentation now arranged in a well-established archive in the Institute's library, was the foundation on which the Institute's international reputation was built. This is why Hutchinson's classic paper defining the modern concept of ecological niche was published in the Memorie (Hutchinson, 1959). Hutchinson's definition of a multidimensional niche provided the newborn science of ecology with a unit of study, while promoting research efforts to quantitatively investigate physical and chemical variables and their seasonal changes and to identify those of key importance for understanding changes in the scene of the ecological theatre (Hutchinson, 1965). Such efforts are documented in early studies on, for example, oxygen concentration (Herbert, 1954), and on how thermal conditions could affect growth and development of lake organisms. The importance of temperature as key variable regulating rates of development and growth of het- 
erotherms, proved under laboratory conditions, was used to develop, for example, the egg ratio method for estimating reproductive rates in field populations (Edmondson, 1960). Edmondson's study pioneered later developments in studies on population dynamics and on mathematical models for investigating populations of species of unknown age and continuous growth, such as those of plankton cladocerans and rotifers (e.g., King, 1967; Kwik and Carter, 1975; Allan, 1976; George and Edwards, 1974; Starkweather et al., 1979).

\section{Studies on plankton ecology and population dynamics}

Studies on dynamics of plankton populations were the basis on which hypotheses regarding the role of both biotic and abiotic variables were identified for testing under natural and laboratory conditions. First of all, we cannot neglect the phytoplankton studies of the " 70 s conducted together with the stimulating and enthusiastic Japanese colleagues on photosynthetic activity of phytoplankton, cell size and bacteria interactions (Kurata et al., 1976; Ruggiu et al., 1979). This ecological aspect was fully embraced by the group and fitted in well with their own awareness of the need for a more holistic view of limnological studies. Quantitative data on demographic and reproductive parameters of zooplankton populations from Lake Maggiore also provided a basis for developing mathematical models (Argentesi et al., 1987) in which seasonal changes in population standing stock density and zooplankton biomass could be analyzed in terms of changes in mortality and fecundity rates. By applying age-specific compartmental models, the specific impacts of different environmental cues, such as food quality, temperature, fish- and invertebrate- predation could be identified. Background information and an incentive for studying size and age specificity of biotic interactions was provided by the publication of the Size Efficiency Hypothesis (Brooks and Dodson, 1965). To achieve this, documentary evidence was arranged and summarized to define sizespecificity governing biotic and abiotic interactions within and between plankton populations (Peters, 1985). The contribution of research studies at the institute was also a consequence of the fact that pioneering studies on fish diet had allowed fish predation to be seen as responsible for shifts in size structure of plankton communities (Giussani and de Bernardi, 1977). The use of mathematical models developed within studies on Lake Maggiore zooplankton also provided a basis for regarding demographic and reproductive parameters of key zooplankton populations (e.g., Daphnia), as tracers for environmental variables. They allowed for the suggestion that biotic interactions are by far the most important factors in regulating community structure (de Bernardi et al., 1987; Manca and Comoli, 1995a; Manca and DeMott, 2009). They supported a view in which open-water plankton organisms were re- garded not only as affected by, but also affecting the, abiotic properties of the environment: at least in the open water, community structure modifies the abiotic environment (de Bernardi, 1981).

Other than independent entities, as in, for example, Forbes' perspective of lakes as microcosms, or as part of basin/catchment basin level, lakes were regarded as an example of fragmented ecosystems, in which local biodiversity could be linked, for example, to transport of resting stages by migratory birds (LAKeS Long-distance dispersal in Aquatic Key Species Project ENV4-CT97-0585;results summarized in Acta Oecologica, 2002; http://www. sciencedirect.com/science/journal/1146609X/23/3). Populations of Cladocera and aquatic plants were studied at the river catchment basin level, which was regarded as a regional unit where a group of connected populations of a given species resulted from the dynamics between increases (births and immigrations) and decreases (deaths and emigrations) of individuals, as well as by the emergence and dissolution of local populations contained within it. By including river catchments located inside and outside the main waterfowl migration routes, the role of local environmental conditions and of bird-mediated transport were investigated for their relative importance in population maintenance of widely distributed aquatic organisms, and for their influence on both biodiversity and gene fluxes. As the migratory patterns of waterfowl are significantly altered by climate change, the project aimed at providing quantitative estimates for researchers involved in modelling the biotic consequences, and predicting the impact of changes in bird migration patterns in Europe on the intra-specific biodiversity of aquatic ecosystems, which could be used in the conservation and management of aquatic biodiversity.

\section{The aquatic microbial ecology of freshwaters}

The role of prokaryotes in biogeochemical cycles was soon recognized in the development of microbiology. However, in the study of inland waters prokaryotes have received relatively little attention compared to the interest in eukaryotes of microscopic size. The cause must be sought in the methodological problems rising when studying microorganisms in very diluted environments such as lakes. The methodological constraints long restricted the study of aquatic microbial ecology to research into the cultivable forms of bacteria growing on rich media, addressing human health rather than ecological issues. However, the significance of water microbes was so obvious that as early as the first volume of the Memorie, published in 1942, a paper appeared dealing with a group of bacteria typical of freshwater ecosystems (Redaelli and Ciferri, 1942).

Studies of the energy source for heterotrophic prokaryotes, that is, the organic matter dissolved or suspended in water, also made slow progress due to the analytical difficulties involved in investigating such a complex and diluted 
pool of molecules. However, the institute made a very early contribution to research into the organic chemistry of sediments and lake waters, providing a first screening of the allochthonous organic molecules in the waters and sediments of Lake Maggiore (Povoledo, 1959a, 1959b). The following decade brought results that shed new light on the ecology of bacterioplankton. It emerged that although only $1 \%$ of aquatic bacteria visible under the optical microscope can be cultivated using traditional methods, the non-cultivable fraction is also active and can grow on liquid culture media containing little carbon. In other words, in waters such as Lake Maggiore, a very large portion of the bacterial community is oligocarbophilic, and grows slowly on very diluted media (Melchiorri-Santolini and Cafarelli, 1967). This finding has led scientists to look for relationships between bacterioplankton and other components of the food chain, obtaining evidence, if not of causal relationships at least of temporal trends to some extent converging with that of phyto-and zooplankton (Melchiorri-Santolini, 1967; Goldman et al., 1968). The relationships between organic detritus and bacterial populations were recognized and widely debated in the symposium on Detritus and its role in aquatic ecosystems, held at the institute in Pallanza in 1972 (MelchiorriSantolini and Hopton, 1972) within the context of the International Biological Program. It was necessary to wait until the mid-Seventies to obtain reliable estimates of the concentration of organic substrate in Italian subalpine lakes and collect analyses of bacterial activity capable of providing a first realistic estimate of the mass and energy transfer within the microbial food chain in Lake Maggiore (Melchiorri-Santolini et al., 1975; Bertoni, 1976).

Meanwhile, commercial instruments for the determination of particulate and dissolved organic carbon became available, enabling the routine measurement of the energy supply for bacteria present in lakes. More selective techniques for microscopic counting of bacteria, using vital dyes and epifluorescence microscopy, also became widespread thus making the routine acquisition of data on the bacterioplankton abundance easy. The evaluation of the long-term evolution of the microbial food chain in relation to climatic changes became thus possible and research on this issue started. The new analytical techniques and the results obtained with them expanded our view of the aquatic microbial world, highlighting the presence in the microbial food chain of other organisms in addition to bacteria. The term picoplankton was coined to describe every microorganism, autotrophic and heterotrophic, with sizes between 0.2 and $2 \mu \mathrm{m}$.

The interest of microbial ecologists has expanded worldwide from bacteria to heterotrophic picoplankton and through to picocyanobacteria, the main constituents of autotrophic picoplankton. These organisms, neglected in traditional phytoplankton studies but clearly visible in epifluorescence microscopy, can be of huge importance as primary producers in oligotrophic lakes such as Lake Maggiore, where they can account for $80 \%$ of the total primary production (Callieri and Stockner, 2000; Callieri, 2008). The climate change issue also captured the interest of aquatic microbiologists given that such change affects the autotrophic and heterotrophic microflora through the modification of the underwater temperature and radiation. Research on the effects on picoplankton of the underwater photosynthetically active radiation (PAR) and of ultraviolet (UV) radiation has therefore received much attention. This research has highlighted the changes in the activity and in the morphology of the autotrophic and heterotrophic picoplankton with increasing intensity of the UV radiation and with modification of the spectral composition of the underwater PAR (Callieri et al., 1996; Vörös et al., 1998; Bertoni and Callieri, 1999; Modenutti et al., 2005; Corno et al., 2009; Callieri et al., 2011). Our ability to analyze the microbial world received a considerable boost from molecular biology, and particularly from DNA amplification and analysis techniques. Such tools made it possible to identify the non-cultivable microorganisms and to assess the evolution in space and time of the two domains included in picoplankton: Bacteria and Archaea. The last group, once considered as extremophilic organisms, can also be mesophilic since they have been found in many lakes, including the deep subalpine lakes, where they conduct important metabolic activities in the nitrogen and carbon cycles. Archaea are more abundant in the hypolimnion while Bacteria dominate the epilimnion, and this niche differentiation is related to different ecological requirements of the two domains. The Archaea are extensively involved in the nitrogen cycle, their organic substrate requirements are lower than those of bacteria and they also synthesize organic matter from inorganic carbon in the deeper aphotic layers of water bodies. This activity observed in marine environments has been confirmed for the first time in a lake with measurements made in the deep hypolimnion of Lake Maggiore and contributing in no small part to the productivity of the lake hypolimnion as a whole (Callieri et al., 2014).

It is now possible to study the phylogeny of heterotrophic and autotrophic picoplankton comparatively, inserting the microorganisms studied in Lake Maggiore in the broader context of the global microbial biodiversity (Callieri et al., 2012, 2013). The long-term series of data on the microbial food chain has made it possible to highlight the ecological changes of Lake Maggiore over the past 30 years, evaluating the different impact of climate change and of direct human impact on the ecosystem. The latter proved to be more significant than climate change and therefore cannot be taken as an excuse for abandoning the practices of good management of the lake adopted and maintained at regional level (Bertoni et al., 2010). It has also been found that climate change, and in particular its 
effects on meteorological events, can cause unusual changes in lake water level, as a result of heavy rainfall and drought periods different from those in the past by intensity and seasonal distribution. These level changes influence, along with the drainage of the catchment area and the changing thermal conditions of the lake, the development of potentially toxic cyanobacteria in oligotrophic lakes such as Lake Maggiore.

Finally, the today available techniques have made it possible to assess the spatial heterogeneity of microbial food chain across the whole surface of Lake Maggiore. This allows the contextualization of the historical measurements carried out in a few spots on Lake Maggiore, which is in fact characterized by a gradient of increasing trophic levels along the north-south axis (Bertoni et al., 2004).

\section{Studies on lake trophic status and trophic evolution}

Along with confronting and contributing to ecological theories, limnological studies have had to deal with the increasing awareness that lakes could be endangered by chemical pollution and by receiving a surplus of algal nutrients carried via rivers and coastal cities, that causing algal blooms (Ravera and Vollenweider, 1968). Such awareness promoted integrated programs aimed at quantifying lake productivity and finding best suitable variables for across-lake comparisons, to define water quality and ecosystem health (e.g., Vollenweider, 1959). Measures of primary productivity had been established at the Istituto since the mid fifties, just a few years after the introduction of ${ }^{14} \mathrm{C}$ method for measuring phytoplankton primary productivity. Lake Maggiore was among the first freshwater environments where the ${ }^{14} \mathrm{C}$ method was applied (Vollenweider and Nauwerck, 1961) and in 1965 the Institute hosted the International Biological Programme (IBP) symposium on Primary productivity in aquatic environments (Goldman, 1966). In the same period the scientific basis of lake eutrophication, with particular reference to phosphorus and nitrogen as eutrophication factors, were studied (Vollenweider, 1965), thus providing a mathematical basis for lake management implementations (Vollenweider, 1968, 1976).

The concerns about the decline in water quality due to eutrophication also promoted the initiation of long-term monitoring programs on lakes. Since the 1970s the institute has been involved in the program for monitoring Lake Maggiore funded by the International Commission for the Protection of Common Italian and Swiss waters (CIPAIS; Mosello et al., 2011). This was fundamental for plans to study lakes at the level of their catchment basins and to quantify specific contributions of tributaries to chemical loadings carried to lakes (Mosello et al., 1991; Rogora et al., 2006). At the lake level, physical and chemical limnology were joined by studies on plankton populations, including bacterioplankton. The lake-watershed approach also allowed for regarding large, deep subalpine lakes as being contributed to by a large number of mountain lakes, in which reserves of species composing, for example, the zooplankton, including glacial relicts, could persist under unaltered environmental conditions. Initiating a monitoring program on Lake Maggiore was essential to draw policymakers' attention to the need to prevent deterioration of water resources. It was also an important step for substantially contributing to the growth of knowledge on lake functioning patterns and mechanisms (Guilizzoni et al., 1996; Guilizzoni et al., 2011; Marchetto et al., 2004). Monitoring is often regarded as a purely descriptive exercise; however, it provided a basis on which general patterns in seasonal dynamics of plankton compartments could be identified and studied, as well as lakes' trophic evolution, such as in the case of Lake Maggiore (Sommer et al., 1986; Ruggiu et al., 1998; Manca and Ruggiu, 1998; Bertoni and Callieri, 1992; Manca et al., 2007; Morabito et al., 2012; Morabito and Manca, 2013). It also provided the series of long-term data that have allowed to establish some of the subalpine lakes studied by the Institute as research sites inside the European Long Term Ecological Research network (LTER; http://www.lter-europe. net/networks/italy/LTER_ITA Sites). The monitoring allowed for detecting anomalous, exceptional events, and for addressing their effects on different ecosystem compartments, therefore revealing mechanisms through which aquatic ecosystems function and are modified by climate change (e.g., Visconti et al., 2008; Manca et al., 2000).

Along with detection of present trophic status, it was highlighted a need for studying trophic evolution and reconstructing pre-eutrophication conditions in as many as possible lakes, also in view of their reliable restoration. To this end, paleolimnological studies were started and sediment cores increasingly used as historical archives of changes in lakes and their catchment basins, a knowledge source for addressing impacts of different perturbations and for integrating and implementing long-term limnological data (Manca and Comoli, 1995b; Marchetto et al., 2013; Guilizzoni et al., 2012; Guilizzoni, 2012).

Starting from 1978 with the participation in the CNR Finalized and Strategic Project on eutrophication, lake sediment cores provide a unique record of environmental changes (eutrophication, acidification) for many Italian ecosystems (sub-alpine, alpine and crater lakes). The most investigated proxy-records and their application to monitoring and plankton dynamics programmes were analysed and discussed in many papers with particular emphasis on the biological remains. Particular prominence was given to fossil pigments (chlorophyll derivatives and carotenoids) as a proxy for past phototrophic communities and primary production, and as biomarkers of environmental changes (Guilizzoni and Lami, 2002). The palaeolimnological techniques were proven to be a 
useful way of improving our understanding of humanclimate ecosystem interactions (Guilizzoni and Oldfield, 1996), and for detecting trophic reference conditions (following the European Water Framework Directive, WFD) mainly using sub-fossil diatoms and pigments (Guilizzoni et al., 2011). Following an initial phase of predominantly descriptive studies, the palaeolimnological studies at the institute focused on developing and improving numerical analysis for quantitative approaches (Marchetto and Bettinetti, 1995). For diatoms, pigments and chrysophytes, transfer functions have been developed from calibration or training sets of modern surface sediment samples collected along environmental gradients (e.g., ecological parameters such as temperature, water $\mathrm{pH}$, nutrients).

Awareness of water resources and of their progressive deterioration promoted efforts aimed at detecting trophic status and measuring to what extent physiological processes of lake ontology (natural eutrophication) were accelerated by means of non-prudent exploitation of resources by humans. Such awareness promoted the funding of projects (by the National Research Council) that the institute, with its director Livia Pirocchi Tonolli, helped plan from the outset. Monitoring of water resources was expanded to include reservoirs, which were built to meet water demand in regions of the country where water availability was constrained by an extremely variable precipitation regime, a prevailing torrential regime of its waterways (CNR Finalized and Strategic Project on eutrophication), and increased water demand (for tourism) during summer (e.g., Sechi and Lugliè, 1992).

Restoration plans successfully promoted reversal to lower trophic status through abatement of phosphorus loadings into lakes and rivers by sewage treatment plants and a reduction of phosphorus in detergents (Mosello et al., 2011; de Bernardi et al., 1990). However, monitoring of restoration plan effects, made it clear that the eutrophication reversal expected after the decrease in nutrient loading and in-lake concentration did not result into a reestablishment of pre-eutrophication biotic communities. The establishment of new, post-reversal communities was not as prompt as chemical restoration: resilience was detected in plankton diversity and community structure in response to phosphorus abatement and chemical restoration. Comparison of common patterns and peculiarities in different lakes allowed for identifying paths and mechanisms responsible for predictable/unpredictable responses of the biota to eutrophication reversal (Sas, 1989; Jeppesen et al., 2005). Variability of time lag in response, depending on trophic position, growth and developmental times of organisms involved, suggested that understanding and predicting recovery processes could not be achieved without assessing ecological roles of the organisms in the environment.

\section{Studies on lake pollution and acidification}

Increasing environmental concern over acid rain and the acidification of waters consequent to anthropogenic atmospheric pollution on a global scale resulted in the development, from the early 1980s, of a 20 -year research effort within programs funded by the European Commission, Directorate General for the Environment (DG-Environment). The Institute's contribution, initially devoted to hydrochemistry of lake water and of atmospheric depositions (Marchetto et al., 1994, 1995; Mosello et al., 1990), gradually expanded to also include various aspects of the biota, from microbial populations to fish (Straškrabová et al., 1999). In particular the Italian Network on Acid deposition (RIDEP) was established in Pallanza. Research focused mainly on alpine environments, as relatively simple systems in which direct and indirect effects of acidification on lake ecosystem structure and functioning could be investigated, by means of multidisciplinary approaches, including paleo- and neo-limnological methods. lakes in the Alps, Pyrenees, Tatras (Western Carpathians), Retezat (Southern Carpathians) and Rila Mountains (Balkans) (in a total of 235) were included into a space-for-time substitution study approach in which a wide range of environmental conditions could be simultaneously represented. Within a series of EUfunded projects focusing on mountain lakes (e.g., AL:PE, AL:PE2, MOLAR, EMERGE), lakes in the Alps were compared to those in other mountain regions of Europe (Marchetto and Rogora, 2004). This extensive effort to compare biotic communities of different sites lead to syntheses in which the relevance of different variables, representative of lake size, tropho-dynamic status, acid-base balance and ice-cover duration (i.e., altitudinal gradient) could be investigated among and within taxonomic groups (Catalan et al., 2009). For each of these variables, thresholds were identified, above and below which ecosystem organisation was found to change substantially. It was found that most assemblages respond to a complex environmental mosaic, rather than to single variables (Marchetto et al., 2009). Overall, programs on lake acidification resulted in a substantial progress in quantitative typologies for environmental quality and biodiversity conservation programmes, and in improving predictions about global change impacts. Studies on acid rain and its impact on aquatic ecosystems changed the view of lake pollution, from site-specific to global, involving a long-distance transport which was, contrary to expectations, considered to affect remote, high mountain lakes, rather than, or in addition to, those more vulnerable to direct human impacts (Camarero et al., 2009; Lami et al., 2000; Lami et al., 2007; Rogora et al., 2008). Such awareness lead to the development of limnological and paleolimnological projects dealing with high altitude environments, including terrestrial, in addition to aquatic, 
ecology, partly promoted by means of the Ev-K2-CNR Committee (Lami et al., 2010).

Initial concern over chemical pollution, particularly by heavy metals, largely focused on a national level and within the institute on Lake Orta, since Rina Monti's first studies (Monti, 1930), in which progressive depletion of life was detected along with the discharge of huge amounts of copper ammonia and sulphate into the lake. Lake Orta was also a case study for acidification, holding the dubious distinction of being the largest acidified lake in the world. Lake Orta, in which heavy metal pollution was also accompanied by acidification, was also among the most advanced and successful examples of how the scientific community was able to impact both policy makers and citizens, promoting recovery plans while developing an awareness of being ecosystem-sound exploitation of water resources economically advantageous (Calderoni et al., 1992). The role the institute played was also important in promoting the establishment of international thresholds for preventing damage by increased heavy metal concentrations in aquatic environments (BCR Reference materials). At a national level, it also promoted approval by the Italian Parliament of a law that officially introduced constraints on water use to prevent water quality deterioration (Merli's Law, 10 May 1976, n. 319).

A point source of DDT pollution of industrial origin, discovered in Lake Maggiore in 1996, created concern, because contamination in some fish species exceeded the threshold for human consumption, even though the concentrations measured in the water were much lower than the legal requirements for drinking purposes (Galassi et al., 2006). This contamination posed serious threats to both top predators and fishery activities (Bettinetti et al., 2005). The Institute has been involved from the outset in the DDT pollution monitoring on behalf of the International Commission for Protection of Common Italian Swiss Waters (CIPAIS) (Guilizzoni, 2013). The monitoring project also focused on Stable Isotope Analyses of zooplankton, to investigate the transfer of pollutants to planktivorous fish. Zooplankton accumulate organochlorine compounds more rapidly than fish and respond much faster than their predators to fluctuations of pollutants occurring in the water column (Bettinetti et al., 2010), therefore proving successful in predicting the contamination of a freshwater environment (Bettinetti et al., 2012). Stable Isotope Analysis was recently extended to calculating Trophic Magnification Factors (TMFs) of novel brominated flame retardants, HBCD, and PBDEs in zooplankton and fish from Lake Maggiore (Poma et al., 2014).

\section{Lakes as sentinels, integrators, and regulators of climate change}

Awareness of a need to study the consequences of global warming on aquatic environments promoted research at the institute aimed at understanding how the in- crease in air temperature might affect water temperature and lake hydrodynamics, as well as the impact on biotic communities. Such interest could benefit from the already established long-term studies on physical limnology and tightly linked to measuring of meteoclimatic variables. Research by the physical limnology group allowed for detecting across-lake consistency of warming trends in deep lakes causing heat accumulation in hypolimnetic layers and changes in winter mixing depth over the last decades (Ambrosetti and Barbanti, 1999). These studies also provided the basis on which between-year variability in population phenology could be traced along with long-term changes in plankton communities (e.g., Salmaso, 2005). The long-established approach of studying lakes along with their tributaries also allowed for detecting and quantifying frequency of occurrence, duration and intensity of extreme rainfall events into the Lake Maggiore catchment basin (Saidi et al., 2012). Intensive efforts to resurrect precipitation data since the early 1920s contributed to our present knowledge of, for example, the extent to which increased frequency of short-term, intense rainfall extreme events impacts the western central subalpine region (Saidi et al., 2013). This goal is vital for preventing catastrophic effects of climate change and to define correct threshold risks for human safety and for the correct dimensioning of human infrastructures. The impact of warming was mainly investigated in terms of understanding and modelling effects on lake hydrodynamics, and the possible impact of changes in, for example, water mixing on biological communities, not least the phytoplankton (Salmaso et al., 2012) and fish (Jeppesen et al., 2012). Research on meteoclimatic variables at a regional level focused more intensively on rivers and streams, and on modelling how, increased occurrence of water level fluctuations impacts landscape, biotic communities, human activities and security, by substantially changing hydrology of waterways (Apel et al., 2004).

While being increasingly solved in areas of the world where it was first detected, eutrophication is a major concern in countries where a rapid economic development has been promoted. Meanwhile, occurrence of eutrophication-like phenomena in restored freshwater environments has become increasingly evident, as a consequence of global warming (Schindler, 2001; Visconti et al., 2008). The interaction between trophy and climate is the challenge we are facing at the global level; this challenge is a unique opportunity for understanding specific paths and mechanisms promoted by climate and nutrient changes, which may result in apparently overlapping, common patterns (Salmaso et al., 2007; Morabito and Manca, 2013). With respect to the past, however, the perspective via which eutrophication, its reversal and interaction with climate change are analyzed focuses far more closely on functional in addition to taxa-specific approaches, broadly 
accepted as the best for understanding impact, containing detrimental effects and preventing non-reversible damages to aquatic ecosystem functioning (Moss et al., 2009).

\section{Present and future challenges}

This necessarily brief and limited analysis of the institute's contribution to limnology and ecology inevitably concludes with a look at the work in progress and at the future goals as the institute is still in development and its research strategies have evolved to take into account the methodological developments of recent years. Closely linked to what has been developed during its history, the Institute is now called upon to make a substantial contribution to research studies on climate change, and water demand, in particular on the role of deep lakes as reservoirs. Climate change and biological invasions are also a key point on which the institute is qualified to investigate (e.g., Riccardi et al., 2004; Riccardi and Giussani, 2007; Kamburska et al., 2013) also thanks to the availability of an excellent database (e.g., Boggero et al., 2014).

\section{Resurrection ecology}

The discovery of sediment cores as a source for resurrecting organisms from the past (resurrection ecology; Kerfoot et al., 1999; Kerfoot and Weider, 2004; Frisch et al., 2014), offers a unique opportunity for quantifying changes in diversity, taxa composition and life strategies of aquatic populations in response to natural and anthropogenic disturbances, adding a dynamic dimension to palaeolimnology (Jeppesen et al., 2001; Guilizzoni, 2012). The hatching of ephippial eggs isolated from sediments of a known age allows for reconstructing changes in life history traits associated with environmental perturbations, included exposure to toxic conditions. The possibility of raising hatchlings obtained from ephippial eggs allows for comparing past $v s$ present populations, to see how they perform in laboratory experiments simulating time-specific environmental conditions. Resurrecting ancestors for transgenerational tests represents a new experimental approach to paleolimnology, answering the vexing question of how to test paleolimnological inferences directly (Kerfoot and Weider, 2004). Indirect estimates of past populations to compare their performance with respect to contemporary ones, under past and present conditions allow for detecting changes in level of tolerance along with, and for identifying mechanisms responsible for the essential ability of species/clones to compete and survive under different perturbations, included heavy metal pollution (Piscia et al., 2014; Frisch et al., 2014).

Among ephippia-producing cladocerans, species of the Daphnia genus are very suitable for resurrection ecology: easy culturing and well established methods for hatching ephippial eggs are coupled with a crucial role in transfer of matter, energy and pollutants, through the pelagic food web. Daphnia has long been a model organism in ecotoxicology, and in the most recent developments of environmental genomics, aimed at understanding genome-environment interactions (Colbourne et al., 2011). Because of a fast population growth rate, as many as 30 successive Daphnia generations may live and die in a lake in a single year. A sediment section dating back half a century ago, for example, allows for comparing life history patterns of organisms from around 1500 generations ago with respect to those currently living in the same environment. The span of living eggs retrieved from sediment cores conforms nicely to the time frame of microevolutionary responses (i.e., multiple generations), therefore offering indirect evidence for microevolutionary changes along with environmental conditions (e.g., Kerfoot and Weider, 2004; Frisch et al., 2014).

\section{Functional diversity}

Functional approaches quantifying diversity by means of organisms' functional traits are increasingly applied to aquatic ecosystems, also in view of understanding and predicting how the system will be able to maintain its operational properties (sensu Moss et al., 2009) under increasing perturbations causing changes in taxa diversity and composition. Functional-based studies are proposed as alternative or complementary to classic, taxonomy-based approaches for example. Species-specific functional traits allow for the defining of species by their ecological roles (Barnett et al., 2013) or by what they do in the ecosystem (Moss et al., 2009), thus contributing to identification of the trophic niche (Elton, 1927; Leibold, 1995).

Despite the importance of the subject, there is no consensus on how to quantify functional diversity within a community and relationships between various indices have not been yet established (Mouchet et al., 2010). A methodology widely used to quantify organisms' trophic roles and trophic interactions is $\mathrm{C}$ and $\mathrm{N}$ Stable Isotope Analysis (C,N SIA). Carbon isotopic signature $\left(\delta^{13} \mathrm{C}\right)$ of a consumer reflects its source of dietary carbon (Peterson and Fry, 1987; Post, 2002), whereas nitrogen isotopic signature $\left(\delta^{15} \mathrm{~N}\right)$ is used to detect its trophic role (Minagawa and Wada, 1984; Post, 2002). Combined measurements of $\delta^{13} \mathrm{C}$ and $\delta^{15} \mathrm{~N}$ are used to examine how basal carbon source(s) of food web(s) is stepwise transferred through trophic levels. In a functional-based perspective, $\mathrm{C}$ and $\mathrm{N}$ isotopic signatures allow for identifying ecological relations (competition and predation, among-taxa vicariance and redundancy) and defining functional groups within and between ecosystem compartments. Stable Isotope Analysis may be regarded as a molecular approach (Strayer, 2010) used as a functional approach (i.e., operational, sensu Moss et al., 2009; Barnett et al., 2013; Kuwae et al., 2012). Often restricted to one or few time spots, SIA is increasingly applied to investigate seasonal 
dynamics in lakes. Interest in applying SIA seasonally is consequent to awareness of aquatic environments being highly variable over time, an attribute deriving from the intrinsic nature of the aquatic medium (Bozelli et al., 2008). Seasonal succession is increasingly regarded as not only taxa-, but also ecologically and functionally informative. Carbon and nitrogen stable isotope analyses have been recently applied to Lake Maggiore monitoring, to investigate seasonal changes in taxa-specific crustacean zooplankton and main planktivorous fish, for highlighting changes in ecological roles and exploitation of carbon sources (Visconti et al., 2014). Bottom-up vs top-down control mechanisms were identified with carbon mainly driven by the former and nitrogen stepwise-enrichment of pelagic preys linearly decreasing with size-specific predation pressure, overall suggesting longer food webs being proportionally less stepwise-enriched than shorter ones. Isotopic signatures of mixed zooplankton in a size fraction edible for the fish were found to vary seasonally, from more ${ }^{15} \mathrm{~N}$-enriched values in winter and fall to less ${ }^{15} \mathrm{~N}$-enriched values in spring and early summer. Changes observed were at least partly related to relative contribution of primary $v s$ secondary zooplankton consumers; basically, under prevalence of primary consumers lower levels of nitrogen enrichment were measured, while an increase in contribution of carnivorous taxa to total zooplankton biomass was related to a higher level of enrichment in nitrogen isotopic signature (Bettinetti and Manca, 2013). Consequences include not last reliable estimates of biomagnification of Persistent Organic Pollutants (POPs; e.g., Poma et al., 2014).

\section{Molecular ecology}

This is concerned with applying molecular phylogenetics, and more recently genomics, proteomics and metabolomics to traditional ecological questions (e.g., species diagnosis, assessment of biodiversity, species-area relationships, organism responses to abiotic and biotic pressures, and many questions in behavioural ecology). To characterize the interactions of organisms with their environment at molecular level, genomics studies genetic material recovered directly from environmental samples, proteomic addresses protein localization and functional cataloguing, and metabolomics assesses organism function and health through metabolites dynamics. Methods frequently include using microsatellites to determine gene flow and hybridization between populations (Colautti et al., 2005; Vergilino et al., 2011; Marková et al., 2013). The development of molecular ecology is also closely related to the use of DNA microarrays, which allows for the simultaneous analysis of the expression of thousands of different genes. Quantitative PCR may also be used to analyze gene expression and their relation with specific picoplanktonic taxa or activity as a result of changes in environmental conditions or different response by differently adapted individuals.

Molecular ecological techniques have recently been used to study in situ questions of prokaryotic (bacterial and archaeal) diversity (Callieri et al., 2009), using CARD FISH (Catalyzed Reporter Deposition Fluorescence In Situ Hybridization) techniques with specific fluorescent probes and subsequent epifluorescence microscopy examination. The relevance of this approach lies in the fact that many aquatic microorganisms cannot be easily cultured in the laboratory, which would allow for their identification and characterisation with classic microbiological methods. The ecological importance of the molecular techniques also stems from the development of PCR (Polymerase Chain Reaction) and Real Time PCR techniques, which allow for rapid amplification of genetic material. The amplification of DNA from environmental samples using general or group-specific primers leads to a mix of genetic material that has to be sorted out before sequencing and identification. The classic technique to achieve this is through temperature gradient gel electrophoresis or through cloning, which involves incorporating the amplified DNA fragments into bacterial plasmids.

Studies at the Institute in cooperation with the University of Montreal at McGill and the University of Windsor, Canada (within the Erasmus CREATE Excellence Program; http://wwwl.uwindsor.ca/erasmus-create/projects; Loria, 2013) are addressed towards investigating mechanisms of evolution of copper tolerance in Daphnia after toxicity tests simulating levels of exposure to copper Daphnia species experienced during long-term lake pollution (by using resurrection ecology techniques). Generation4 microarrays will be applied for detecting differences in the transcription of genes after copper toxicity tests (Colbourne, 2011).

\section{CONCLUSIONS}

We hope having opened a window onto past research at the Institute, with this concise overview of its achievements to date being at least sufficient to give a rough idea of its pivotal role in limnology and its ability to help orientate environmental managers.

However, we should not underestimate the extent to which research at the institute has contributed to the development of ecology. The golden age of the institute has been unequivocally recorded on paper. During the Second World War and far beyond, the institute was an incubator, not only for limnology, but also for the modern natural sciences and ecology in Italy. Buzzati, Cavalli, Pirocchi, Tonolli and others promoted a great step forward, towards an innovative methodological approach: the hypothesis driven and quantitative natural sciences representing a clear distinction from the previous, mainly descriptive, approach. Moreover, the interaction of so many great sci- 
entists was the first example of interdisciplinary science. During the 50's and 60's, the roots of the Italian ecology were established in Pallanza, thanks to the influence of ecologists mainly from the U.S. Not least Hutchinson (and Wetzel, Goldman, Edmondson, Deevey, Margalef, Vollenweider, Peters), who were not only great aquatic ecologists, but primarily great theoretical ecologists. The institute was an incubator for ideas which influenced young Italian scientists such as Antonio Moroni and Norberto Della Croce, who ten years later founded the Italian Society of Ecology (SItE) and the Italian Association of Oceanography and Limnology (AIOL), with fundamental support by Livia Pirocchi Tonolli. In the 1960s, the Institute greatly contributed to the International Biological Program (IBP), which was fundamental for the development of modern limnology and of theoretical ecology. Maybe, is not by chance that the top Italian ecologists are mainly aquatic ecologists.

Thus, a few questions, to conclude:

"Has the research of the Institute produced new theories or improved the old ones?"

"Has the research of the Institute produced theories or datasets of some diagnostic or predictive value?"

We are confident you can answer yes at least to one question. If this is the case, the research of the Institute has not been meaningless and the question why limnology? (Rigler and Peters, 1995) will once again find an answer.

\section{ACKNOWLEDGMENTS}

We dedicate this paper to Professor Livia Tonolli, former Director of the Istituto Italiano di Idrobiologia (now Istituto per lo Studio degli Ecosistemi) for promoting and supporting limnological research. We would as well acknowledge the English language revision by Neil Davenport.

\section{REFERENCES}

Allan JD, 1976. Life history patterns in zooplankton. Am. Nat. $165-180$.

Ambrosetti W, Barbanti L, 1999. Deep water warming in lakes: an indicator of climatic change. J. Limnol. 58:1-9.

Apel H, Thieken AH, Merz B, Blöschl G, 2004. Flood risk assessment and associated uncertainty. Nat. Hazards Earth Syst Sci. 4:295-308.

Argentesi F, de Bernardi R, Di Cola G, Manca M, 1987. Mathematical modelling of Daphnia populations. In: R.H. Peters and R. de Bernardi (eds.), Daphnia. Mem. Ist. Ital. Idrobiol. 45:389-412.

Baldi E, 1941. Ricerche idrobiologiche sul Lago di Tovel. Mem. Museo Storia Natur. Ven. Trid. 6:1-297.

Baldi E, 1942. Problemi della limnobiologia italiana. Mem. Ist. Ital. Idrobiol. 1:321-344.

Baldi E, 1950. Phenomenes de microevolution dans les populations planktiques d'eau douce. Viert. Nat. Ges. Zurich 95: 89-114.
Baldi E, Pirocchi L, 1939. [Genetische Ausblicke in der Limnologie]. Arch. Hydrobiol. 36:126-154.

Baldi E, Buzzati-Traverso A, Cavalli LL, Pirocchi L, 1945a. [Frammentamento di una popolazione specifica (Mixodiaptomus laciniatus Lill.) in un grande lago in sottopopolazioni geneticamente differenziate]. [Article in Italian]. Mem. Ist. Ital. Idrobiol. 2:167-216.

Baldi E, Cavalli LL, Pirocchi L, 1945b. [Condizioni della distribuzione del mesoplancton nel pelago di un grande lago oligotrofo (Lago Maggiore)]. [Article in Italian]. Mem. Ist. Ital. Idrobiol. 2:253-289.

Baldi E, Cavalli LL, Pirocchi L, Tonolli V, 1949. [L'isolamento delle popolazioni di Mixodiaptomus laciniatus Lill. del Lago Maggiore e i suoi nuovi problemi]. [Article in Italian]. Mem. Ist. Ital. Idrobiol. 5:295-305.

Barnett AJ, Finlay K, Beisner BE, 2013. Functional diversity of crustacean zooplankton communities: towards a trait-based classification. Freshwater Biol. 52:796-813.

Bertoni R, 1976. A four year study of the spatial and temporal variations of microseston and heterotrophic bacterial microflora in Lago Maggiore. Mem. Ist. Ital. Idrobiol. 33:433-444.

Bertoni R, Callieri C, 1992. Research trends in the study of microbial loop. In: P. Guilizzoni, G. Tartari and G. Giussani (eds.), Limnology in Italy. Mem. Ist. Ital. Idrobiol. 50:107-116.

Bertoni R, Callieri C, 1999. Effects of UV-B radiation on freshwater autotrophic and heterotrophic picoplancton in a subalpine lake. J. Plankton Res. 21:1373-1388.

Bertoni R, Piscia R, Callieri C, 2004. Horizontal heterogeneity of seston, organic carbon and picoplankton in the photic zone of Lago Maggiore, Northern Italy. J. Limnol. 63: 244-249.

Bertoni R, Callieri C, Corno G, Rasconi S, Caravati E, Contesini M, 2010. Long-term trends of epilimnetic and hypolimnetic bacteria and organic carbon in a deep holo-oligomictic lake. Hydrobiologia 644: 279-287.

Bettinetti R, Croce V, Galassi S, 2005. Ecological risk assessment for the recent case of DDT pollution in Lake Maggiore (Northern Italy). Water Air Soil Pollut. 162: 385-399.

Bettinetti R, Galassi S, Guzzella L, Quadroni S, Volta P, 2010. The role of zooplankton in DDT biomagnification in a pelagic food web of Lake Maggiore (Northern Italy). Environ. Sci. Pollut. Res. 17: 1508-1518.

Bettinetti R, Manca M, (2013). Understanding the role of zooplankton in transfer of pollutants through trophic food webs. Nova Science Publishers Inc., Hauppauge, NY (in press).

Bettinetti R, Quadroni S, Manca M, Piscia R, Volta P, Guzzella L, Roscioli C, Galassi S, 2012. Seasonal fluctuations of DDTs and PCBs in zooplankton and fish of Lake Maggiore (Northern Italy). Chemosphere 88:344-351.

Boggero A, Basset A, Austoni M, Barbone E, Bartolozzi L, Bertani I, Cattaneo A, Cianferoni F, Corriero G, Dörrh AM, Elia C, Ficetola GF, Kamburska L, La Porta G, Lauceri S, Ludovisi A, Gaino E, Goretti E, Lorenzoni M, Manca M, Marchetto A, Morabito G, Nonnis Marzano F, Oggioni A, Pierrig C, Riccardi N, Rossetti G, Ungaro N, Volta P, Zaupa S, Fontaneto D, (2014). Weak effects of habitat type on susceptibility to invasive freshwater species: an Italian case study. Aquat. Conserv. (in press).

Bossone A, Tonolli V, 1954. [Il problema della convivenza di Arctodiaptomus bacillifer (Koelb), di Acanthodiaptomus 
denticornis (Wierz.) e di Heterocope saliens Lill]. [Article in Italian]. Mem. Ist. Ital. Idrobiol. 8:81-94.

Bozelli RL, Tonsi M, Sandrini F, Manca M, 2008. A Big Bang or small bangs? Effects of biotic environment on hatching. J. Limnol. 67: 100-106.

Brooks JL, Dodson SI, 1965. Predation, body size, and composition of plankton. Science 150:28- 35 .

Buzzati-Traverso A, 1945. [Sull'indeterminazione e la casualità nei fenomeni biologici]. [Article in Italian]. Analisi 1:102-109.

Buzzati-Traverso A, Cavalli LL, 1945. [Fenotipi e costituzione genetica di una popolazione di Drosophila melanogaster]. [Article in Italian]. Mem. Ist. ital. Idrobiol. 2:217-251.

Calderoni A, Mosello R, Ruggiu D, 1992. Sixty years of limnology on Lago d'Orta: a case history from heavy pollution. In: P. Guilizzoni, G. Tartari and G. Giussani (eds.), Limnology in Italy. Mem. Ist. Ital. Idrobiol. 50:201-224.

Callieri C, 2008. Picophytoplankton in freshwater ecosystems: the importance of small-sized phototrophs. Freshwater Reviews 1:1-28.

Callieri C, Amicucci E, Bertoni R, Vörös L, 1996. Fluorometric characterization of two picocyanobacteria strains from lakes of different underwater light quality. Internat. Rev. ges. Hydrobiol. 81: 13-23.

Callieri C, Stockner J, 2000. Picocyanobacteria success in oligotrophic lakes: fact or fiction? J. Limnol. 59:72-76.

Callieri C, Corno G, Caravati E, Rasconi S, Contesini M, Bertoni R, 2009. Bacteria, Archaea and Crenarchaeota in the epilimnion and hypolimnion of a deep holo-oligomictic lake. Appl. Environ. Microbiol. 75:7298-7300.

Callieri C, Lami A, Bertoni R, 2011. Microcolony formation by single-cell Synechococcus strains as a fast response to UV radiation. Appl. Env. Microbiol. 77:7533-7540.

Callieri C, Caravati E, Corno G, Bertoni R, 2012. Picocyanobacterial community structure and space-time dynamics in the subalpine Lake Maggiore (N. Italy). J. Limnol. 71:e9.

Callieri C, Coci M, Corno G, Macek M, Modenutti B, Balseiro E, Bertoni R, 2013. Phylogenetic diversity of nonmarine picocyanobacteria. FEMS Microbiol. Ecol. 85:293-301.

Callieri C, Coci M, Eckert EM, Salcher MM, Bertoni R, 2014. Archaea and Bacteria in deep lake hypolimnion: in situ dark inorganic carbon uptake. J. Limnol. 73:47-54.

Camarero L, Rogora M, Mosello R, Anderson J, Barbieri A, Botev I, Kernan M, Kopacěk J, Korhola A, Lotter A, Muri G, Postolache C, Stuchlik E, Thies H, Wright RF, 2009. Regionalisation of chemical variability in European mountain lakes. Freshwater Biol. 54:2452-2469.

Catalan J, Barbieri MG, Bartumeus F, Bitusik P, Botev I, Brancelj A, Cogalniceanu D, Manca M, Marchetto A, Ognjanova-Rumenova N, Pla S, Rieradevall M, Sorvari S, Stefkova E, Stuchlik E, Ventura M, 2009. Ecological thresholds in European alpine lakes. Freshwat. Biol. 54:2494-2517.

Cavalli LL, 1949. [Analisi della multivarianza applicata al differenziamento delle popolazioni di Mixodiaptomus laciniatus del Lago Maggiore]. [Article in Italian]. Mem. Ist. Ital. Idrobiol. 5:307-315.

Colautti RI, Manca M, Viljanen M, Ketelaars HAM, Bürgi H, MacIsaac HJ, Heath DD, 2005. Invasion genetics of the Eurasian spiny waterflea: evidence for bottlenecks and gene flow using microsatellite data. Mol. Ecol. 14:1869-1879.

Colbourne JK, 2011. Genomics for the environment. Invited lec- ture at the $9^{\text {th }}$ Int. Symp. on Cladocera. Verbania, Italy, 2-8 October 2011.

Colbourne JK, Pfrender ME, Gilbert D, Thomas WK, Tucker A, Oakley TH, Tokishita S, Aerts A, Arnold GJ, Basu MK, Bauer DJ, Cáceres CE, Carmel L, Casola C, Choi J-H, Detter JC, Dong Q, Dusheyko S, Eads BD, Fröhlich TF, GeilerSamerotte KA, Gerlach D, Hatcher P, Jogdeo S, Krijgsveld J, Kriventseva EV, Kültz D, Laforsch C, Lindquist E, Lopez J, Manak JR, Muller J, Pangilinan J, Patwardhan RP, Pitluck SP, Pritham EJ, Rechtsteiner AR, Rho M, Rogozin IB, Sakarya O, Salamov A, Schaack S, Shapiro H, Shiga Y, Skalitzky C, Smith Z, Souvorov A, Sung W, Tang Z, Tsuchiya D, Tu H, Vos H, Wang M, Wolf YI, Yamagata H, Yamada T, Ye Y, Shaw JR, Andrews J, Crease TJ, Tang T, Lucas SM, Robertson HM, Bork P, Koonin EV, Zdobnov EM, Grigoriev IV, Lynch M, Boore JL, Tsuchiya D, 2011. The ecoresponsive genome of Daphnia pulex. Science 331:555-561.

Corno G, Modenutti B, Callieri C, Balseiro E, Bertoni R, Caravati E, 2009. Bacterial diversity and morphology in deep ultraoligotrophic Andean lakes: role of UVR on vertical distribution. Limnol. Oceanogr. 54:1098-1112.

de Bernardi R, 1981. Biotic interactions in freshwater and effects on community structure. Boll. Zool. 48:353-371.

de Bernardi R, Giussani G, Manca M, 1987. Cladocera: predators and prey. Hydrobiologia 145:225-243.

de Bernardi R, Giussani G, Manca M, Ruggiu D, 1990. Trophic status and the pelagic system in Lago Maggiore. Hydrobiologia 191:1-8.

Dobzhansky T, 1937. Genetics and the origin of species. Columbia Univ. Press, New York: 446 pp.

Edmondson WT, 1960. Reproductive rates of rotifers in natural populations. Mem. Ist. Ital. Idrobiol. 12: 21-77.

Elton CS, 1927. Animal ecology. University of Chicago Press: 209 pp.

Frisch D, Morton PK, Chowdhury PR, Culver BW, Colbourne JK, Weider LJ, Jeyasingh PD, 2014. A millennial-scale chronicle of evolutionary responses to cultural eutrophication in Daphnia. Ecol. Lett. 17:360-368.

Galassi S, Volta P, Calderoni A, Guzzella L, 2006. Cycling pp'DDT and pp'DDE at a watershed scale: the case of Lago Maggiore (Italy). J. Limnol. 65:100-106.

George DG, Edwards RW, 1974. Population dynamics and production of Daphnia hyalina in a eutrophic reservoir. Freshwat. Biol. 4: 445-465.

Giussani G, de Bernardi R, 1977. Food selectivity in Coregonus sp.[zooplanktophagous fish] of Lake Maggiore [Italy]: an energetical approach. Mem. Ist. Ital. Idrobiol. 34:121-130.

Goldman CR, 1966. Primary productivity in aquatic environments. Proc. Int. Biological Programme Symp., Pallanza, Italy. University of California Press: $467 \mathrm{pp}$.

Goldman CR, Gerletti M, Javornicky P, Melchiorri-Santolini U, De Amezaga E, 1968. Primary productivity, bacteria, phytoand zooplankton in Lake Maggiore: correlations and relationships with ecological factors. Mem. Ist. Ital. Idrobiol. 23: 49-127.

Guilizzoni P, 2012. Paleolimnology: an introduction. In: B. Gopal (ed.) Limnology of rivers and lakes - Encyclopedia of Life Support Systems (EOLSS), Eolss Publ. Accessed on January 15, 2013. Available from: http://www.eolss.net 
Guilizzoni P, 2013. [Indagini su DDT e sostanze pericolose nell'ecosistema del Lago Maggiore. Rapporto annuale 2012. Rapporto finale 2008-2012]. [in Italian]. Commissione internazionale per la protezione delle acque italo-svizzere: $151 \mathrm{pp}$.

Guilizzoni P, Oldfield F, 1996. Palaeoenvironmental analysis of Italian crater lake and Adriatic sediments (PALICLAS). Mem. Ist. Ital. Idrobiol.: 357 pp.

Guilizzoni P, Marchetto A, Lami A, Cameron NG, Appleby PG, Rose NL, Schnell AØ, Belis CA, Giorgis A, Guzzi L, 1996. The environmental history of a mountain lake (Lago Paione Superiore, Central Alps, Italy) for the last c. 100 years: a multidisciplinary, paleolimnological study. J. Paleolimnol. 15:245-264.

Guilizzoni P, Lami A, 2002. Paleolimnology: use of algal pigments as indicators, p. 2306-2317. In: G. Bitton (ed), The encyclopedia of environmental microbiology. Wiley and Sons.

Guilizzoni P, Marchetto A, Lami A, Gerli S, Musazzi S, 2011. Use of sedimentary pigments to infer past phosphorus concentration in lakes. J. Paleolimnol. 45:433-445.

Guilizzoni P, Levine SN, Manca M, Marchetto A, Lami A, Ambrosetti W, Brauer A, Gerli S, Carrara EA, Rolla A, Guzzella L, Vignati DAL, 2012. Ecological effects of multiple stressors on a deep lake (Lago Maggiore, Italy) integrating neo and palaeolimnological approaches. J. Limnol. 71:e1.

Herbert M, 1954. The tolerance of oxygen deficiency in the water by certain Cladocera. Mem. Ist. Ital. Idrobiol. 8:97-107.

Hutchinson GE, 1957. A Treatise on Limnology. 2. J. Wiley \& Sons New York: 1115 pp.

Hutchinson GE, 1959. Il concetto moderno di nicchia ecologica. Mem. Ist. Ital. Idrobiol. 11:9-22.

Hutchinson GE, 1965. The ecological theater and the evolutionary play. Yale University Press: 139 pp.

Jeppesen E, Leavitt P, De Meester L, Jensen JP, 2001. Functional ecology and palaeolimnology: using cladoceran remains to reconstruct anthropogenic impact. Trends Ecol. Evol. 16:191-198.

Jeppesen E, Mehner T, Winfield IJ, Kangur K, Sarvala J, Gerdeaux D, Rask M, Malmquist HJ, Holmgren K, Volta P, Romo S, Eckmann R, Sandström A, Blanco S, Kangur A, Ragnarsson H, Stabo M, Meerhoff A, Ventelä M, Søndergaard TL, Lauridsen, 2012. Impacts of climate warming on the long-term dynamics of key fish species in 24 European Lakes. Hydrobiologia 694:1-39.

Jeppesen E, Sondergaard M, Jensen JP, Havens KE, Anneville O, Carvalho L, Coveney MF, Deneke R, Dokulil MT, Foy B, Gerdeaux D, Hampton SE, Hilt S, Kangur K, Köhler J, Lammens EHHR, Lauridsen TL, Manca M, Miracle MR, Moss B, Nöges P, Persson G, Philipps G, Portielje R, Romo S, Schelske CL, Straile D, Tatrai I, Wille E, Winder M, 2005. lake responses to reduced nutrient loading - an analysis of contemporary long-term data from 35 case studies. Freshwater Biol. 50:1747-1771.

Kamburska L, Lauceri R, Beltrami M, Boggero A, Cardeccia A, Guarneri I, Manca M, Riccardi N, 2013b. Establishment of Corbicula fluminea (O.F. Müller, 1774) in Lake Maggiore: a spatial approach to trace the invasion dynamics. BioInvasions Records 2:105-117.

Kerfoot WC, Robbins JA, Weider LJ, 1999. A new approach to historical reconstruction: combining descriptive and experimental paleolimnology. Limnol. Oceanogr. 44:1232-1247.
Kerfoot WC, Weider LJ, 2004. Experimental paleoecology (resurrection ecology): chasing Van Valen's Red Queen hypothesis. Limnol. Oceanogr. 49:1300-1316.

King CE, 1967. Food, age, and the dynamics of a laboratory population of rotifers. Ecology 48:111-128.

Kurata AC, Saraceni C, Ruggiu D, Nakanishi M, MelchiorriSantolini U, Kadota H, 1976. Relationship between B group vitamins and primary production and phytoplankton population in Lake Mergozzo (Northern Italy). Mem. Ist. ital. Idrobiol. 33: 257-284.

Kuwae T, Miyoshi E, Hosokawa S, Ichimi K, Hosoya J, Amano T, Morya, Kondoh, Ydenberg RC, Elner RW, 2012. Variable and complex food web structures revealed by exploring missing trophic links between birds and biofilm. Ecol. Lett. 15:347-356.

Kwik JK, Carter JC, 1975. Population dynamics of limnetic Cladocera in a beaver pond. J. Fish. Board Can. 32:341-346.

Lami A, Guilizzoni P, Marchetto A, 2000. High resolution analysis of fossil pigments, carbon, nitrogen and sulphur in the sediments of eight European Alpine lakes: the MOLAR project. In: A. Lami, N. Cameron and A. Korhola (eds.), Paleolimnology and Ecosystem Dynamics at Remote European Alpine lakes. J. Limnol. 59:15-28.

Lami A, Tartari GA, Musazzi S, Guilizzoni P, Marchetto A, Manca M, Boggero A, Nocentini AM, Morabito G, Tartari G, Guzzella L, Bertoni R, Callieri C, 2007. High latitude lakes: limnology and paleolimnology. In: R. Baudo, G. Tartari and E.Vuillermoz (eds.), Mountains: witnesses and global changes. Developments in Earth Surface Processes book series, Elsevier 10:155-170.

Lami A, Marchetto A, Musazzi S, Salerno F, Tartari G, Guilizzoni P, Rogora M, Tartari GA, 2010. Chemical and biological response of two small lakes in the Khumbu Valley, Himalayas (Nepal) to short term variability and climatic change as detected by long-term monitoring and paleolimnological methods. Hydrobiologia 648:189-205.

Leibold MA, 1995. The niche concept revisited: mechanistic models and community context. Ecology 76:1371-1382.

Loria A, 2013. Coping with metal stress: mechanisms of evolution of copper tolerance in Daphnia. PhD Candidate supervisor Meeting. University of Montreal at McGill, December 2013.

Manca M, Comoli P, 1995a. Seasonal changes in size of the feeding basket of Leptodora kindtii (Focke) in Lago Maggiore as related to variations in prey size selection. Limnol. Oceanogr. 40: 834-838.

Manca M, Comoli P, 1995b. Temporal variations of fossil Cladocera in the sediments of Lake Orta (N. Italy) over the last 400 years. J. Paleolimnol. 14:113-122.

Manca M, Cavicchioni N, Morabito G, 2000. First observations on the effect of complete overturn of Lake Maggiore on plankton and primary production. Int. Rev. Hydrobiol. 85:209-222.

Manca M, DeMott WR, 2009. Response of the invertebrate predator Bythotrephes to a climate-linked increase in the duration of a refuge from fish predation. Limnol. Oceanogr. 54:2506-2512.

Manca M, Ruggiu D, 1998. Consequences of pelagic food-web changes during a long-term lake oligotrophication process. Limnol. Oceanogr. 43:1368-1373. 
Manca M, Torretta B, Comoli P, Amsinck SL, Jeppesen E, 2007. Major changes in trophic dynamics in large, deep sub-alpine Lake Maggiore from 1940s to 2002: a high resolution comparative palaeo-neolimnological study. Freshwater Biol. 52:2256-2269.

Marchetto A, Ariztegui D, Brauer A, Lami A, Mercuri AM, Sadori L, Vigliotti L, Wulf S, Guilizzoni P, (2013). Crater lake sediments as sensitive archives of climate and environmental change, In. D. Rouwet, B. Christenson, F. Tassi and J. Vandemeulebrouck (eds.), Volcanic lakes, Springer-Heidelberg (in press).

Marchetto A, Bettinetti R, 1995. Reconstruction of the phosphorus history of two deep, subalpine Italian lakes from sedimentary diatoms, compared with long-term chemical measurements. Mem. Ist. Ital. Idrobiol. 53:27-37.

Marchetto A, Lami A, Musazzi S, Massaferro J, Langone L, Guilizzoni P, 2004. Lago Maggiore (N. Italy) trophic history: fossil diatoms, plant pigments, chironomids and comparison with long-term limnological data. Quatern. Int. 113:97-110.

Marchetto A, Mosello R, Psenner R, Barbieri A, Bendetta G, Tait D, Tartari GA, 1994. Evaluation of the level of acidification and the critical loads for Alpine lakes. Ambio 23: 150-154.

Marchetto A, Mosello R, Psenner R, Bendetta G, Boggero A, Tait D, Tartari GA, 1995. Factors affecting water chemistry of Alpine lakes. Aquatic Sci. 57:81-89.

Marchetto A, Rogora M, 2004. Measured and modelled trends in European mountain lakes. J. Limnol. 63:55-62.

Marchetto A, Rogora M, Boggero A, Musazzi S, Lami A, Lotter AF, Tolotti M, Thies H, Psenner R, Massaferro J, Barbieri A, 2009. Response of alpine lakes to major environmental gradients, as detected through planktonic, benthic and sedimentary assemblages. Adv. Limnol. 62:419-440.

Margalef R, 1965. Ecological correlations and the relationship between primary productivity and community structure. Mem. Ist. Ital. Idrobiol. 18:355-364.

Margalef R, 1990. Limnology: reconsidering ways and goals. Mem. Ist. Ital. Idrobiol. 47:57-76.

Marková S, Dufresne F, Manca M, Kotlík P, 2013. Mitochondrial capture misleads about ecological speciation in the Daphnia pulex complex. PLOS one DOI: 10.1371/journal.pone. 0069497.

Melchiorri-Santolini U, 1967. [Rapporti ecologici tra zooplancton e microflora batterica negli ambienti limnici]. [Article in Italian]. B. Zool. 34:139-140.

Melchiorri-Santolini U, Cafarelli A, 1967. Lake water as a medium to cultivate fresh water pelagic bacteria. Mem. Ist. Ital. Idrobiol. 22:289-298.

Melchiorri-Santolini U, Hopton JW, 1972. Detritus and its role in aquatic ecosystems. Proc. IBP-UNESCO Symp. Mem. Ist. Ital. Idrobiol. Suppl. 29:548 pp.

Melchiorri-Santolini U, Bertoni R, Maestroni GJ, Mariazzi AA, 1975. Distribution of pelagic bacterial population and related ecological factor in a deep lake. In: T. Hasegawa (ed.). Developmental microbiology, ecology. Proc. $1^{\text {st }}$ Intersect. Cong. Int. Assoc. Microbiol. Soc. 2:385-394.

Minagawa M, Wada E, 1984. Stepwise enrichment of ${ }^{15} \mathrm{~N}$ along food chains: Further evidence and the relation between $\delta^{15} \mathrm{~N}$ and animal age. Geochim. Cosmochi. Ac. 48:1135-1140.
Modenutti B, Balseiro E, Callieri C, Bertoni R, Queimaliños C, 2005. Effect of UV-B and different PAR intensities on the primary production of the mixotrophic planktonic ciliate Stentor araucanus. Limnol. Oceanogr. 50:864-871.

Monti R, 1930. [La graduale estinzione della vita nel limnobio del Lago d'Orta]. [Article in Italian]. Rend. Ist. Lomb. Sc. Lett. 63:3-22.

Morabito G, Manca M, 2013. Eutrophication and recovery of the large and deep subalpine Lake Maggiore: patterns, trends and interactions of planktonic organisms between trophic and climatic forcings. In: A. Lambert and C. Roux (Eds), Eutrophication: Causes, Economic Implications and Future Challenges. Nova Publishers: in press.

Morabito G, Oggioni A, Austoni M, 2012. Resource ratio and human impact: how diatom assemblages in Lake Maggiore responded to oligotrophication and climatic variability. Hydrobiologia 698:47-60.

Mosello R, Bertoni R, Guilizzoni P, 2011. Limnological and palaeolimnological research on Lake Maggiore as a contribution to transboundary cooperation between Italy and Switzerland, p. 167-167. In: J. Ganoulis, A. Aureli and J. Fried (eds.), Transboundary water resources management: a multidisciplinary approach, $1^{\text {st }}$ ed. Wiley-VCH Verlag.

Mosello R, Marchetto A, Boggero A, Tartari GA, 1990. Relationships between water chemistry, geographical and lithological features of the watershed of Alpine lakes located in NW Italy. Verh. Internat. Verein. Limnol. 24:155-157.

Mosello R, Ruggiu D, Pugnetti A, Moretti M, 1991. Observed trends in the trophic conditions and possible recovery of the deep subalpine Lake Como (Northern Italy). Mem. Ist. Ital. Idrobiol. 49:79-98.

Moss BD, Hering AJ, Green AA, Becares E, Beklioglu M, Bennion H, Boix D, Brucet S, Carvalho L, Clement B, Davidson T, Declerck S, Dobson M, van Donk E, Dudley B, Feuchtmayr H, Friberg N, Grenouillet G, Hillebrand H, Hobaek A, Irvine K, Jeppesen E, Johnson R, Jones I, Kernan M, Lauridsen TL, Manca M, Meerhoff M, Olafsson J, Ormerod S, Papastergiadou E, Penning WE, Ptacnik R, Quintana X, Sandin L, Seferlis M, Simpson G, Triga C, Verdonschot P, Verschoor AM, Weyhenmeyer GA, 2009. Climate change and the future of freshwater biodiversity in Europe: a primer for policy-makers. Freshwater Reviews 2:103-130.

Mouchet MA, Villeger S, Mason NW, Mouillot D, 2010. Functional diversity measures: an overview of their redundancy and their ability to discriminate community assembly rules. Func. Ecol. 24: 867-876.

Peters RH, 1985. Seasonal and trophic effects on size structure of the planktonic communities in four lakes of northern Italy. Mem. Ist. Ital. Idrobiol. 43:91-104.

Peterson BJ, Fry B, 1987. Stable isotopes in ecosystem studies. Annu. Rev. Ecol. Syst. 18:293-320.

Piscia R, Colombini M, Ponti B, Bettinetti R, Monticelli D, Rossi V, Manca M, (2014). Lifetime response of contemporary vs resurrected Daphnia galeata Sars (Crustacea, Cladocera) to $\mathrm{Cu}$ (II) chronic exposure. Aquat. Toxicol. (in press).

Poma G, Volta P, Roscioli C, Bettinetti R, Guzzella L, (2014). Concentrations and trophic interactions of novel brominated flame retardants, HBCD, and PBDES in zooplankton and fish from Lake Maggiore (Northern Italy). Science of Total Environment (in press). 
Post DM, 2002. Using stable isotopes to estimate trophic position: models, methods, and assumptions. Ecology 83:703-718.

Povoledo D, 1959a. [Studi chimici sulle sostanze organiche azotate sedimentarie e sestoniche di alcuni laghi dell'Italia settentrionale]. [Article in Italian]. Mem. Ist. Ital. Idrobiol. 11:25-60.

Povoledo D, 1959b. [Sulla presenza di chetoacidi nei sedimenti di alcuni laghi dell'Italia settentrionale]. [Article in Italian]. Mem. Ist. Ital. Idrobiol. 11:113-132.

Ravera O, 1955. Seasonal variation of the reproductive rate in pelagic Copepods of Lago Maggiore. Proc. Int. Ass. theor. Appl. Limnol. 12:436-446.

Ravera O, Vollenweider RA, 1968. Oscillatoria rubescens D.C. as an indicator of Lago Maggiore eutrophication. Schweiz. Z. Hydrol. 30:374-380.

Redaelli P, Ciferri R, 1942. [Primi reperti di Caulobacteriales aquadulcicoli italiani.] [Article in Italian]. Mem. Ist. Ital. Idrobiol. 1:107-114.

Riccardi N, Giussani G, 2007. The relevance of life history traits in the establishment of the invader Eudiaptomus gracilis and the extinction of Eudiaptomus padanus in Lake Candia (Northern Italy): evidence for competitive exclusion? Aquat. Ecol. 41:243-254.

Riccardi N, Giussani G, Margaritora F, Couchaud B, 2004. Population dynamics of the pioneer population of Daphnia parvula, Fordyce during the invasion of Lake Candia (Northern Italy). J. Limnol. 63:44-52.

Rigler FH, Peters RH, 1995. Science and limnology. Excellence in Ecol. V. 6. Ecol. Inst. Oldendorf/Luhe: 239 pp.

Rogora M, Massaferro J, Marchetto A, Tartari GA, Mosello R, 2008. The water chemistry of Northern Patagonian lakes and their nitrogen status in comparison with remote lakes in different regions of the globe. J. Limnol. 67:75-86.

Rogora M, Mosello R, Calderoni A, Barbieri A, 2006. Nitrogen budget of a subalpine lake in north-western Italy: the role of atmospheric input in the upward trend of nitrogen concentrations. Verh. Internat. Verein. Limnol. 29: 2027-2030.

Ruggiu D, Morabito G, Panzani P, Pugnetti A, 1998. Trends and relations among basic phytoplankton characteristics in the course of the long-term oligotrophication of Lake Maggiore (Italy). Hydrobiologia 369/360:243-257.

Ruggiu D, Saraceni C, De Bortoli T, Nakanishi M, 1979. Primary production in Lago di Mergozzo (N. Italy) and implications of phytoplankton cell size. Mem. Ist. Ital. Idrobiol. 37:223-246.

Saidi H, Ciampittiello M, Dresti C, Ghiglieri G, 2012. The climatic characteristics of extreme precipitations for short-term intervals in the watershed of Lake Maggiore. Theor. Appl. Clim. 113:1-15.

Saidi H, Ciampittiello M, Dresti C, Ghiglieri G, 2013. Observed variability and trends in extreme rainfall indices and PeaksOver-Threshold series. Hydrol. Earth Syst. Sci. Discuss 10:6049-6079.

Salmaso N, 2005. Effects of climatic fluctuations and vertical mixing on the interannual trophic variability of Lake Garda, Italy. Limnol. Oceanogr. 50:553-565.

Salmaso N, Buzzi F, Garibaldi L, Morabito G, Simona M, 2012. Effects of nutrient availability and temperature on phyto- plankton development: a case study from large lakes south of the Alps. Aquat. Sci. 74:555-570.

Salmaso N, Morabito G, Garibaldi L, Mosello R, 2007. Trophic development of the deep lakes south of the Alps: a comparative analysis. Fund. Appl. Limnol 170:177-196.

Sas H, 1989. Lake restoration by reduction of nutrient loading: expectations, experiences, extrapolations. Academia Verlag, Richarz: 497 pp.

Schindler DW, 2001. The cumulative effects of climate warming and other human stresses on Canadian freshwaters in the new millennium. Can. J. Fish. Aquat. Sci. 58:18-29.

Sechi N, Luglié A, 1992. Limnological studies on man-made lakes in Sardinia (Italy). In: P. Guilizzoni, G. Tartari and G. Giussani (eds.), Limnology in Italy. Mem. Ist. Ital. Idrobiol. 50:365-382.

Sommer U, Gliwicz ZM, Lampert W, Duncan A, 1986. The PEG-model of seasonal succession of planktonic events in fresh waters. Arch. Hydrobiol. 106:433-471.

Starkweather PL, Gilbert JJ, Frost TM, 1979. Bacterial feeding by the rotifer Brachionus calyciflorus: clearance and ingestion rates, behavior and population dynamics. Oecologia 44:26-30.

Straškrabová V, Callieri C, Fott J, 1999. Pelagic food web in mountain lakes. MOuntain LAkes Research Program. J. Limnol. 58:127-130.

Strayer DL, 2010. Alien species in fresh waters: ecological effects, interactions with other stressors, and prospects for the future. Freshwat. Biol. 55:152-174.

Tonolli V, 1951. A new device for continuous quantitative plankton sampling: the Plankton-bar. Proc. Int. Ass. Theor. Appl. Limnol. 11:422-429.

Tonolli V, 1954. [Rete da plancton con registrazione di profondità e temperatura]. [Article in Italian]. Mem. Ist. Ital. Idrobiol. 8: 153-162.

Vergilino R, Marková S, Ventura M, Manca M, Dufresne F, 2011. Reticulate evolution of the Daphnia pulex complex as revealed by nuclear markers. Mol. Ecol 20:1191-1207.

Visconti A, Manca M, de Bernardi R, 2008. Eutrophicationlike response to climate warming: an analysis of Lago Maggiore (N. Italy) zooplankton in contrasting years. J. Limnol. 67:87-92.

Visconti A, Volta P, Fadda A, Di Guardo A, Manca M, 2014. Seasonality, littoral vs. pelagic carbon sources and stepwise ${ }^{15} \mathrm{~N}$-enrichment of 2 pelagic food web in a deep subalpine lake: the role of planktivorous fish. Can. J. Fish Aquat. Sci. 71:1-11.

Vollenweider RA, 1959. [Alcune osservazioni sulla dinamica dell'ossigeno nel Lago Maggiore (Bacino di Pallanza)]. [Article in Italian]. Mem. Ist. Ital. Idrobiol. 11:241-264.

Vollenweider RA, 1965. Calculation models of photosynthesis depth curves and some implications regarding day rate estimates in primary production measurements. Mem. Ist. Ital. Idrobiol. Suppl. 18: 425-457.

Vollenweider RA, 1968. The scientific basis of lake and stream eutrophication, with particular reference to phosphorus and nitrogen as eutrophication factors. Tech. Rep. OECD DAS/CSI/68 27:1-182.

Vollenweider RA, 1976. Advances in defining critical loading levels for phosphorus in lake eutrophication. Mem. Ist. Ital. Idrobiol. 33:53-83.

Vollenweider RA, 1990. Eutrophication: conventional and non- 
conventional considerations and comments on selected topics. In: R. de Bernardi, G. Giussani and L. Barbanti (eds.), Scientific perspectives in theoretical and applied limnology. Mem. Ist. Ital. Idrobiol. 47:77-138.

Vollenweider RA, Nauwerck A, 1961. Some observations on the ${ }^{14} \mathrm{C}$ method for measuring primary production. Verh. Int. Ver. Limnol. 14:134-139.
Vörös L, Callieri C, Balogh KV, Bertoni R, 1998. Freshwater picocyanobacteria along a trophic gradient and light quality range. Hydrobiologia 368/370:117-125.

Wright S, 1932. The roles of mutation, inbreeding, crossbreeding, and selection in evolution. Proc. $6^{\text {th }}$ Int. Cong. Genetics 1:356-366. 